\title{
Organic solvent tolerant metallo protease of novel isolate Serratia marcescens PPB-26: production and characterization
}

\author{
Shikha Thakur ${ }^{1} \cdot$ Nirmal Kant Sharma $^{1} \cdot$ Neerja Thakur $^{1} \cdot$ Savitri $^{1} \cdot$ \\ Tek Chand Bhalla ${ }^{1}$
}

Received: 23 June 2016/Accepted: 16 August 2016/Published online: 26 August 2016

(c) The Author(s) 2016. This article is published with open access at Springerlink.com

\begin{abstract}
Proteases are a class of enzymes that catalyze hydrolysis of peptide bonds of proteins. In this study, 221 proteolytic bacterial isolates were obtained by enrichment culture method from soils of various regions of Himachal Pradesh, India. From these a hyper producer of protease was screened and identified by morphological and physiological testing and by $16 \mathrm{~S}$ rDNA sequence as Serratia marcescens PPB-26. Statistical optimization of physiochemical parameters enhanced the protease production by $75 \%$. Protease of S. marcescens PPB-26 was classified as a metalloprotease. It showed optimal activity at $30{ }^{\circ} \mathrm{C}, \mathrm{pH}$ 7.5 (0.15 M Tris- $\mathrm{HCl}$ buffer) and with $0.8 \%$ substrate concentration. It had $K_{\mathrm{m}}=0.3 \%, V_{\max }=34.5 \mu \mathrm{mol}$ $\min ^{-1} \mathrm{mg}^{-1}$ protein and a half life of 2 days at $30^{\circ} \mathrm{C}$. The enzyme was stable in most metal ions but showed increased activity with $\mathrm{Fe}^{2+}$ and $\mathrm{Cu}^{2+}$ while strong inhibition with $\mathrm{Co}^{2+}$ and $\mathrm{Zn}^{2+}$. Further investigation showed that the enzyme could not only retain its activity in various organic solvents but also showed increased activity with methanol and ethanol. The reported metalloprotease is thus a potential candidate for carrying out industrial peptide synthesis.
\end{abstract}

Keywords Serratia marcescens - Organic solvent tolerant protease $\cdot$ Metalloprotease $\cdot 16 \mathrm{~S}$ rDNA sequencing . Response surface methodology

Tek Chand Bhalla

bhallatc@rediffmail.com

1 Department of Biotechnology, Himachal Pradesh University, Summer Hill, Shimla, Himachal Pradesh 171005, India

\section{Introduction}

Proteases, also known as peptidases belong to a larger group of enzymes called hydrolases which catalyze hydrolysis of bonds with the participation of a water molecule. They can be exoproteases or endoproteases depending on their site of action. On the basis of mechanism of catalysis, endoproteases are divided into aspartic proteases, cysteine proteases, metalloproteases, serine proteases and threonine proteases (Barrett et al. 2001). Metalloproteases are most diverse of all proteases (Barrett and Rawlings 1995). They require a divalent metal ion for their activity and are, therefore, inhibited by chelating agents such as EDTA (Miyoshi and Shinoda 2000). The metal ion acts by activating a water molecule which serves as nucleophile in the catalysis. Most metalloproteases contain $\mathrm{Zn}^{2+}$ while a few contain $\mathrm{Mg}^{2+}, \mathrm{Ni}^{2+}$ or $\mathrm{Cu}^{2+}$. Various microbial strains such as Bacillus subtilis, Bacillus megaterium, Bacillus cereus, B. thuringiensis, Listeria monocytogenes, Serratia marcescens AP3801 and Serratia sp. KCK have been reported to produce metalloproteases (Morita et al. 1997; Miyoshi and Shinoda 2000; Kim et al. 2007).

Proteases execute a large variety of complex physiological functions and their importance in conducting the essential metabolic and regulatory functions is evident from their occurrence in all living organisms. However, microbes are their most preferred source due to their rapid growth, limited space requirement and ease in genetic manipulation (Kocher and Mishra 2009). Among microbes, bacteria are the most common source of commercial proteases (Gupta et al. 2002). Bacterial proteases are mostly extracellular, easily produced in large amounts, thermostable and active at wide $\mathrm{pH}$ range. These properties make them most suitable for wide industrial applications. 
Due to the growing market of proteases worldwide efforts for isolation of novel bacterial species from underexploited regions and niche habitats that produce proteolytic enzymes with novel properties suitable for industrial applications, are underway.

Industrially, proteases are one of the most important categories of enzymes. They find application in variety of industries such as detergents, leather, food, textile and pharmaceutical industries (Ajithkumar et al. 2003; Bhaskar et al. 2007; Jellouli et al. 2009; Annapurna et al. 2012). Besides this, they are also used in waste treatment, peptide synthesis, diagnostic reagents and silver recovery from X-ray/photographic films (Rao et al. 1998; Bhalla et al. 1999; Upadhyay et al. 2010). Enzymatic peptide synthesis has attracted a great deal of attention in recent years. Hydrolysis of peptide bond by proteases in an aqueous environment is a reversible process and can be made to proceed towards peptide bond synthesis under water restricted environment. It has several advantages over chemical methods due to stereospecificity of the proteases, side-chain protection, non-toxic nature of solvents and recyclability of reagents (Morihara 1987). Most proteases, however, are inactive or show low activity in non-aqueous media (Vulfson et al. 2001). Several strategies have been employed to increase enzyme stability in non-aqueous environment such as protein engineering (Wolff et al. 1996) co-lyophilization with inorganic salts ( $\mathrm{Ru}$ et al. 2000), chemical modification of amino acids on enzyme surfaces (Davis 2003), using supercritical fluids (Davis 2003) and using ionic liquids (Noritomi et al. 2009) However, to screen for naturally evolved solvent tolerant enzymes is more economical and cost effective. Thus, finding solvent stable protease has made an extensive area of research.

The present communication reports isolation of a novel protease source, i.e., S. marcescens PPB-26 from previously unexplored regions of Himachal Pradesh (H.P), statistical optimization of protease production and its characterization for potential in industrial applications.

\section{Materials and methods}

\section{Chemicals}

Different media components were obtained from Hi-Media (Mumbai, India). All other chemicals used were of analytical grade and procured from standard companies.

\section{Sample collection}

Soil samples for isolation of proteolytic bacteria were collected aseptically from various regions of Himachal
Pradesh (Shimla, Kullu, Manikaran, Manali, Kinnaur and Bilaspur) from sites that were rich in decaying garden waste, farm waste and industrial effluents. The samples were collected in sterile crew capped tubes and stored at $4{ }^{\circ} \mathrm{C}$ for further processing. The samples were processed within $24 \mathrm{~h}$ of collection.

\section{Isolation of bacteria for protease activity}

Enrichment culture technique was used for isolation of proteolytic bacteria. One gram of soil samples were added into $50 \mathrm{ml}$ minimal salt medium (MSM) supplemented with $1 \%$ casein. Composition of the MSM broth $(\mathrm{g} / \mathrm{l})$ was: glucose, 1; peptone, 10; yeast extract, $0.2 ; \mathrm{CaCl}_{2}, 0.1$; $\mathrm{K}_{2} \mathrm{HPO}_{4}, 0.5 ; \mathrm{MgSO}_{4}, 0.1$ and casein, $10, \mathrm{pH}$ 7. The culture was grown for $24 \mathrm{~h}$ at $155 \mathrm{rpm}$ in $30{ }^{\circ} \mathrm{C}$ temperature. Subsequent enrichments were done and after the third enrichment $1 \mathrm{ml}$ culture broth was serially diluted to $10^{-4}$ $10^{-6}$ times with physiological saline. The diluted inoculum $(0.1 \mathrm{ml})$ was then plated on nutrient agar plates and incubated for $48 \mathrm{~h}$ at $30^{\circ} \mathrm{C}$. Bacterial colonies obtained were purified by sub-culturing and then preserved in nutrient agar slants kept at $4{ }^{\circ} \mathrm{C}$.

\section{Screening of bacterial isolates for protease activity}

Primary screening was done by streaking the isolates on $1 \%$ skim milk agar plates and incubating overnight at $30{ }^{\circ} \mathrm{C}$. Formation of clear zones around colonies indicated digestion of the milk protein and hence extracellular protease activity. Isolates showing strong protease activity were subjected to secondary screening by qualitative determination of their protease activity.

\section{Assay of protease activity}

Protease activity in the isolates was assayed using the method developed by Manachini et al. (1988). Test reaction contained $4 \mathrm{ml}$ of substrate solution, i.e., $0.5 \% \mathrm{w} / \mathrm{v}$ casein in $50 \mathrm{mM}$ potassium phosphate buffer $(\mathrm{pH} \mathrm{7)}$ and $1 \mathrm{ml}$ of enzyme, while in control experiment no enzyme was added. Both reactions were incubated at $30{ }^{\circ} \mathrm{C}$ and then stopped after $20 \mathrm{~min}$ by adding $5 \mathrm{ml}$ of $5 \% \mathrm{w} / \mathrm{v}$ trichloro acetic acid and vortexed. They were then centrifuged $(10,000 \times g$ for $5 \mathrm{~min})$ and absorbance of supernatants measured by spectrophotometer at $275 \mathrm{~nm}$.

\section{Characterization and strain identification}

Physiological and biochemical characterization of the selected isolate PPB-26 was performed as per Bergey's manual, using HiIMViCTM Biochemical Test Kit (Code no.: KB001) (HiMedia Laboratories Pvt. Ltd). Preliminary 
testing involved gram staining, spore formation, acid production tests (from glucose, adonitol, arabinose, lactose, sorbitol, mannitol, rhamnose and sucrose), indole test, methyl red test, Voges Proskauer test and citrate utilization test. Final identification was done by $16 \mathrm{~S}$ rDNA gene sequence analysis. Genomic DNA of the selected isolate was extracted and 16S rDNA gene amplified by PCR using universal primers $27 \mathrm{~F}\left(5^{\prime}\right.$-AGA GTT TGA TCC TGG CTC AG-3') and $1541 \mathrm{R}\left(5^{\prime}\right.$-AAG GAG GTG ATC CAG CCG $\mathrm{CA}-3^{\prime}$ ). PCR products were purified and sequenced by Microbial Type Culture Collection and Gene Bank (MTCC), Institute of Microbial Technology, Chandigarh, India. The related sequences were obtained from GenBank database [National Centre for Biotechnology Information (NCBI), USA] using BLAST search programme and then aligned using the CLUSTAL $\mathrm{W}$ programme. A phylogenetic tree was then finally constructed using MegAlign software.

\section{Optimization of culture parameters for protease production}

Following culture parameters were optimized using the OVAT (one variable at a time) approach.

\section{Selection of growth medium}

Optimum growth media was selected by growing $S$. marcescens PPB-26 in twelve different media (M1-M12) which have previously been reported in literature. $50 \mathrm{ml}$ of nutrient broth $(\mathrm{pH} 7)$ was used as seed media and the culture was incubated over night at $30{ }^{\circ} \mathrm{C}$ in an incubator shaker $(155 \mathrm{rpm}) .2 \%$ of inoculum from the seed media was then added to $50 \mathrm{ml}$ of M1-M12 production media which were further incubated in incubator shaker $(155 \mathrm{rpm})$ at $30{ }^{\circ} \mathrm{C}$. After $24 \mathrm{~h}$ the cells were harvested by centrifugation $(10,000 \times g$ for $15 \mathrm{~min})$ and the protease activity in their supernatant was assayed.

\section{Effect of carbon sources and its concentration}

The effect of 12 different carbon sources on protease production was studied by supplementing $50 \mathrm{ml}$ of the selected growth media with $2 \%(\mathrm{w} / \mathrm{v})$ of different carbon sources (starch, sucrose, maltose, mannitol, glycerol, lactose, galactose, fructose, dextrose, sodium acetate, sodium citrate and sodium succinate). The media were inoculated with $2 \%$ inoculum from the seed media and incubated in incubator shaker $(155 \mathrm{rpm})$ at $30{ }^{\circ} \mathrm{C}$ for $24 \mathrm{~h}$. Protease activity in each was assayed as described in the preceding section. After selection of the suitable carbon source it was used in different concentrations (1-4\%) in the production medium to optimize its concentration.

\section{Effect of nitrogen sources and its concentration}

To evaluate the effect of nitrogen sources on protease production, $S$. marcescens PPB-26 was grown in $50 \mathrm{ml}$ each of production media supplemented with $1 \%(\mathrm{w} / \mathrm{v})$ of various organic and inorganic nitrogen sources (casein, yeast extract, beef extract, peptone, tryptone, soya meal, urea, ammonium sulphate, ammonium phosphate and ammonium nitrate). Incubation was done at $30^{\circ} \mathrm{C}$ in an incubator shaker $(155 \mathrm{rpm})$ for $24 \mathrm{~h}$ and then protease activity assayed. After selection of suitable nitrogen source its concentration was further optimized between 1 and $4 \%$ in a manner similar to the preceding section.

\section{Effect of metal ions}

Eight different metal ions were tested for their effect on protease production. $1 \mathrm{mM}$ of metal ions $\left(\mathrm{CaCl}_{2} \cdot 2 \mathrm{H}_{2} \mathrm{O}\right.$, $\mathrm{CoCl}_{2} \cdot 6 \mathrm{H}_{2} \mathrm{O}, \mathrm{MgCl}_{2} \cdot 6 \mathrm{H}_{2} \mathrm{O}, \mathrm{MnCl}_{2} \cdot 6 \mathrm{H}_{2} \mathrm{O}, \mathrm{CuSO}_{4} \cdot 5 \mathrm{H}_{2} \mathrm{O}$, $\mathrm{MnSO}_{4} \cdot \mathrm{H}_{2} \mathrm{O}, \mathrm{FeSO}_{4} \cdot 7 \mathrm{H}_{2} \mathrm{O}$ and $\left.\mathrm{ZnSO}_{4} \cdot 7 \mathrm{H}_{2} \mathrm{O}\right)$ were added to $50 \mathrm{ml}$ each of the production media. $2 \%$ seed inoculum was added to these media and incubated at $30{ }^{\circ} \mathrm{C}$ for $24 \mathrm{~h}$ in an incubator shaker $(155 \mathrm{rpm})$. Assays for protease activity were then carried out and the suitable metal ion selected.

\section{Incubation time}

To find the optimum duration of incubation of $S$. marcescens PPB-26 for highest protease production, the organism was cultured in optimized growth conditions in an incubator shaker $(155 \mathrm{rpm})$ at $30{ }^{\circ} \mathrm{C}$ for $56 \mathrm{~h}$. Protease activity and cell growth in the media were recorded at regular intervals up to $56 \mathrm{~h}$ and the optimum incubation time was evaluated.

\section{Factorial design for statistical optimization of culture conditions}

Design Expert software 9.0 was used to study the simultaneous effect of 11 independent variables on protease production by $S$. marcescens PPB-26. Using the software a Plackett-Burman design was generated having various combinations of high and low levels of the variables $(\mathrm{pH}$, 5.0-9.0; temperature, $20-40{ }^{\circ} \mathrm{C}$; dextrose, $0.5-5.0 \%$; tryptone, $0.1-2.0 \%$; casein, $0-2.0 \%$; yeast extract, 0.1-1.0 \%; zinc sulphate, $0-0.01 \%$; potassium phosphate, 0-0.5\%; calcium chloride, $0-0.1 \%$; magnesium sulphate, $0-0.1 \%$ and sodium chloride, $0-1.0 \%$ ). 12 different sets of experiments were performed in accordance with the design and protease activity in each case was assayed. The results were analyzed using the software and a Pareto chart was generated. From this chart, variables having

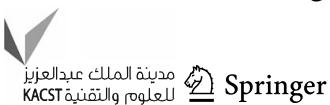


positive effect on protease production were selected. Further a central composite design (CCD) was formed and 20 sets of experiments carried out to optimize concentration of the selected variables. The statistical model was validated for optimal production of protease by carrying out the experiment in a shake flask under the predicted set of conditions.

\section{Optimization of reaction conditions for the protease assay}

\section{Buffer system}

To find out the optimum $\mathrm{pH}$ for protease activity, the reaction was carried out in various buffers of different $\mathrm{pH}$ at $30{ }^{\circ} \mathrm{C}$ for $20 \mathrm{~min}$. Various buffer systems (citrate buffer, $\mathrm{pH}$ 4.0-6.0; Tris-HCl buffer, $\mathrm{pH}$ 7.0-9.0; potassium phosphate buffer, $\mathrm{pH}$ 6.0-8.0 and acetate buffer, $\mathrm{pH}$ 4.0-6.0) were used at a concentration of $0.1 \mathrm{M}$. After selection of the buffer, its molarity was optimized in the range of 25-200 $\mathrm{mM}$.

\section{Reaction temperature}

Reaction temperature for the optimal activity of protease was found by carrying out reaction assays in $0.15 \mathrm{M}$ Tris$\mathrm{HCl}$ buffer $(\mathrm{pH} 7.5)$ at different temperatures $\left(25-50{ }^{\circ} \mathrm{C}\right)$.

\section{Substrate concentration}

The effect of substrate (casein) concentration on the activity of protease of $S$. marcescens PPB-26 was studied by varying it in the range of $0.1-1.0 \%$ in the reaction mixture.

\section{Reaction time}

To evaluate the optimum reaction time for activity of the crude protease, assay was carried out at different incubation times $(2.5-60 \mathrm{~min})$.

\section{Effect of metal ions}

The effect of various metal ions $\left(\mathrm{CoCl}_{2}, \mathrm{FeCl}_{2}, \mathrm{MnCl}_{2}\right.$ $4 \mathrm{H}_{2} \mathrm{O}, \mathrm{CuSO}_{4} \cdot 5 \mathrm{H}_{2} \mathrm{O}, \mathrm{FeSO}_{4} \cdot 7 \mathrm{H}_{2} \mathrm{O}, \mathrm{MnSO} \cdot \mathrm{H}_{2} \mathrm{O}, \mathrm{ZnSO}_{4}$ $7 \mathrm{H}_{2} \mathrm{O}, \mathrm{MgSO}_{4} \cdot 7 \mathrm{H}_{2} \mathrm{O}$ and $\mathrm{CaCl}_{2} \cdot 2 \mathrm{H}_{2} \mathrm{O}$ ) on protease activity was tested by carrying out the reaction in the presence of $2 \mathrm{mM}$ concentration of metals ions, at $30{ }^{\circ} \mathrm{C}$ for $10 \mathrm{~min}$.

\section{Effect of $\mathrm{NaCl}$}

The protease assay of $S$. marcescens PPB-26 was carried out in the presence of different concentrations of $\mathrm{NaCl}$
(0.1-0.9 M) and its effect on the enzyme activity was studied.

\section{Effect of organic solvents}

The crude protease enzyme was pre-incubated with $50 \%$ $(\mathrm{v} / \mathrm{v})$ of various organic solvents. The effect of these organic solvents (acetone, acetonitrile, benzene, butanol, ethanol, isopropyl alcohol and methanol) on enzyme stability was studied by assaying the protease activity.

\section{Results}

\section{Morphological and biochemical characteristics}

Two hundred and twenty-one bacterial isolates were obtained from different soil samples. Isolate PPB-26, which emerged as a hyper producer of protease among all isolates was found to be a Gram negative, straight rod shaped, non-spore forming microbe. It shows negative results with indole test, methyl red test and Voges Proskauer test but was positive for citrate utilization. Further it was capable of glucose, adonitol, arabinose, sorbitol, mannitol and sucrose utilization but showed negative results for lactose and rhamnose.

\section{S rDNA gene sequencing}

The sequence of isolate PPB-26, obtained by $16 \mathrm{~S}$ rDNA gene sequencing was deposited in the NCBI GenBank database with accession number KJ735909. Phylogenetic analysis (Fig. 1) of this sequence revealed $99 \%$ sequence similarity with $S$. marcescens strain SA1 (HM136580.1) indicating that isolate PPB-26 was closely related to it. Thus, on the basis of physiological and biochemical characteristics and on comparison of its 16S rDNA sequence the strain was identified as $S$. marcescens and named as $S$. marcescens PPB-26.

\section{Optimization of Culture Parameters for Protease Production by $S$. marcescens PPB-26}

\section{Media optimization}

Serratia marcescens PPB-26 was cultured in 12 different media (Table 1) and medium M2 containing (g/l) $20.0 \mathrm{~g}$ glucose, $4.0 \mathrm{~g}$ yeast extract, $1.5 \mathrm{~g}$ potassium phosphate, $0.5 \mathrm{~g}$ magnesium sulphate, $0.5 \mathrm{~g}$ calcium chloride and $10 \mathrm{~g}$ casein proved to be the best media for protease production since in it, highest protease activity was observed $(9 \mathrm{U} / \mathrm{mg}$ protein). 
Fig. 1 Phylogenetic dendrogram based on the $16 \mathrm{~S}$ rDNA gene sequences

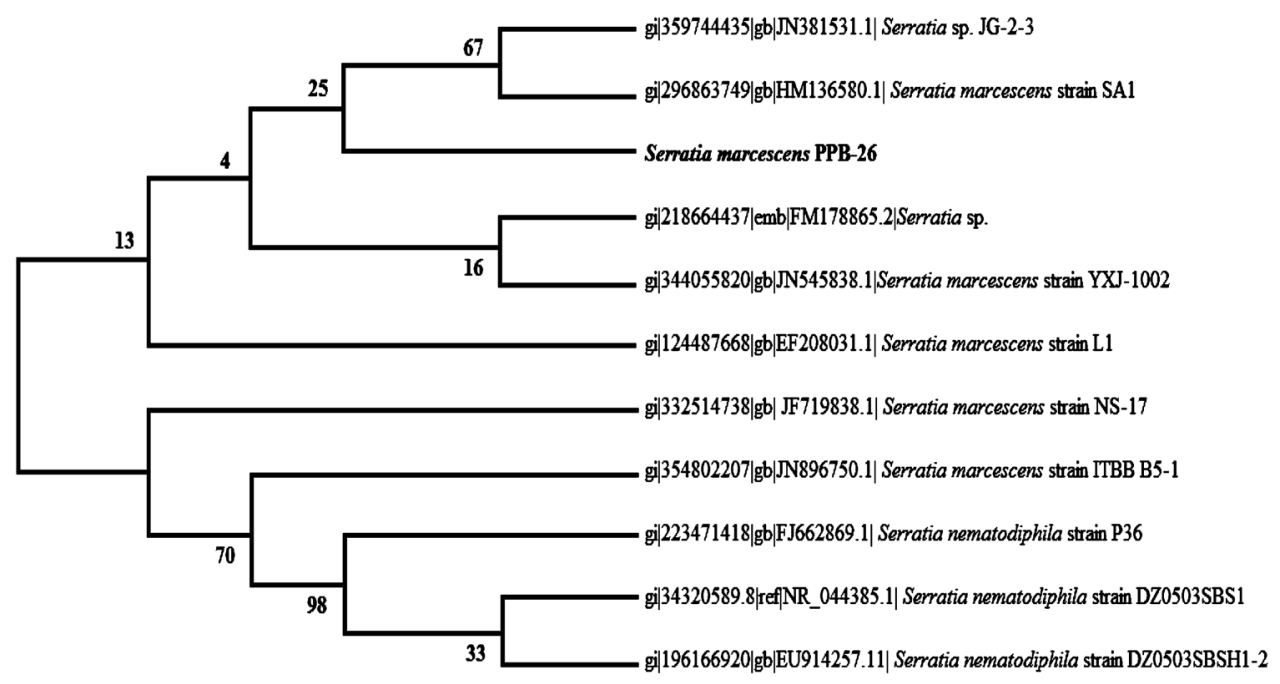

Table 1 Different media used for protease production by $S$. marcescens $\mathrm{PPB}-26$

\begin{tabular}{lll}
\hline $\begin{array}{l}\text { Medium } \\
\text { code }\end{array}$ & $\begin{array}{l}\text { Specific activity } \\
\text { (U/mg of protein) }\end{array}$ & References \\
\hline M1 & 8.1 & GYP medium \\
M2 & 9 & GYC medium \\
M3 & 5 & Sinha and Satyanarayana (1991) \\
M4 & 0.3 & Chu et al. (1992) \\
M5 & 5.6 & Nutrient casein broth \\
M6 & 3 & Tsuchiya et al. (1991) \\
M7 & 8.1 & Tsujibo et al. (1990) \\
M8 & 8.7 & Matta et al. (1997) \\
M9 & 8.6 & Purva et al. (1998) \\
M10 & 8.7 & Tsuchida et al. (1986) \\
M11 & 8.5 & Kobayashi et al. (1995) \\
M12 & 8.1 & Minimal medium \\
\hline
\end{tabular}

Carbon source

Among various carbon sources maximum protease activity (9.02 U/mg protein) was recorded in media supplemented with dextrose. The concentration of dextrose was further optimized and $2.5 \%$ was found to be the most suitable.

\section{Nitrogen source}

Maximum protease activity (9.4 U/mg protein) was observed in media containing tryptone as the nitrogen source. Optimum concentration of tryptone was found to be $1.5 \%$. Protease production by $S$. marcescens PPB-26 was higher in organic nitrogen sources than in inorganic sources.

\section{Metal ions}

In media supplemented with $1 \mathrm{mM} \mathrm{CaCl} 2$ the highest protease activity (10 U/mg protein) was observed.
However, with metal ions $\mathrm{MnCl}_{2}$ (4 U/mg protein) and $\mathrm{MnSO}_{4}(8.5 \mathrm{U} / \mathrm{mg}$ protein) an inhibition in enzyme activity was recorded.

\section{Incubation time}

The activity profile of $S$. marcescens PPB-26 protease studied over a growth period of $56 \mathrm{~h}$ shows a sharp increase in protease activity after $12 \mathrm{~h}$, i.e., during exponential growth phase of $S$. marcescens PPB-26. Maximum protease activity $(10.03 \mathrm{U} / \mathrm{mg}$ protein) was recorded at $24 \mathrm{~h}$ of incubation. There after the protease activity stayed stable till $54 \mathrm{~h}$ and later declined gradually.

\section{Statistical optimization}

Results of experiments performed in accordance with the Plackett-Burman design are shown in Table 2. Highest protease activity obtained from this design was $9.8 \mathrm{U} / \mathrm{mg}$ protein. Using the responses from these set of experiments a Pareto Chart (Fig. 2a) was generated which shows the order of significance of variables on protease production by S. marcescens PPB-26. The chart showed that yeast extract, potassium phosphate and calcium chloride had the greatest positive effect on protease production. A central composite design was thus generated taking different combinations of these three variables. Twenty different sets of experiments were performed according to this design (Table 3) varying the concentrations of these three variables while keeping the concentrations of all other variables constant $(2.5 \%$ dextrose, $0.5 \%$ magnesium sulphate, $1 \%$ casein, $1.5 \%$ tryptone, $\mathrm{pH} 7.0$ and temperature $30{ }^{\circ} \mathrm{C}$ ). Highest protease activity was obtained in the set containing $1 \%$ yeast extract, $0.5 \%$ potassium phosphate and $0.25 \%$ calcium chloride. Optimized concentrations of the three selected variables were further validated by three dimensional (3D) 
Table 2 Plackett-Burman experimental design for production of proteolytic activity

\begin{tabular}{|c|c|c|c|c|c|c|c|c|c|c|c|c|}
\hline Run & $\mathrm{pH}$ & $\begin{array}{l}\text { Temperature } \\
\left({ }^{\circ} \mathrm{C}\right)\end{array}$ & $\begin{array}{l}\text { Dextrose } \\
(\%)\end{array}$ & $\begin{array}{l}\text { Tryptone } \\
(\%)\end{array}$ & $\begin{array}{l}\text { Casein } \\
(\%)\end{array}$ & $\begin{array}{l}\text { Yeast } \\
\text { Ext. (\%) }\end{array}$ & $\begin{array}{l}\mathrm{ZnSO}_{4} \\
(\%)\end{array}$ & $\begin{array}{l}\mathrm{KH}_{2} \mathrm{PO}_{4} \\
(\%)\end{array}$ & $\begin{array}{l}\mathrm{CaCl}_{2} \\
(\%)\end{array}$ & $\begin{array}{l}\mathrm{MgSO} 4 \\
(\%)\end{array}$ & $\begin{array}{l}\mathrm{NaCl} \\
(\%)\end{array}$ & $\begin{array}{l}\text { Response } \\
\text { (U/mg protein) }\end{array}$ \\
\hline 1 & 9.0 & 20 & 5.0 & 2.0 & 0 & 1.0 & 0.01 & 0.5 & 0 & 0 & 0 & 9.0 \\
\hline 2 & 9.0 & 40 & 0.5 & 2.0 & 2.0 & 1.0 & 0 & 0 & 0 & 0.1 & 0 & 0 \\
\hline 3 & 5.0 & 20 & 5.0 & 0.1 & 2.0 & 1.0 & 0 & 0.5 & 0.1 & 0.1 & 0 & 9.8 \\
\hline 4 & 9.0 & 40 & 5.0 & 0.1 & 0 & 0.1 & 0.01 & 0 & 0.1 & 0.1 & 0 & 0 \\
\hline 5 & 9.0 & 40 & 0.5 & 0.1 & 0 & 1.0 & 0 & 0.5 & 0.1 & 0 & 1.0 & 0 \\
\hline 6 & 5.0 & 40 & 5.0 & 0.1 & 2.0 & 1.0 & 0.01 & 0 & 0 & 0 & 1.0 & 1.0 \\
\hline 7 & 5.0 & 40 & 5.0 & 2.0 & 0 & 0.1 & 0 & 0.5 & 0 & 0.1 & 1.0 & 0 \\
\hline 8 & 9.0 & 20 & 0.5 & 0.1 & 2.0 & 0.1 & 0.01 & 0.5 & 0 & 0.1 & 1.0 & 2.6 \\
\hline 9 & 5.0 & 20 & 0.5 & 0.1 & 0 & 0.1 & 0 & 0 & 0 & 0 & 0 & 0 \\
\hline 10 & 9.0 & 20 & 5.0 & 2.0 & 2.0 & 0.1 & 0 & 0 & 0.1 & 0 & 1.0 & 1.163 \\
\hline 11 & 5.0 & 40 & 0.5 & 2.0 & 2.0 & 0.1 & 0.01 & 0.5 & 0.1 & 0 & 0 & 0.0078 \\
\hline 12 & 5.0 & 20 & 0.5 & 2.0 & 0 & 1.0 & 0.01 & 0 & 0.1 & 0.1 & 1.0 & 7.0 \\
\hline
\end{tabular}

response surface plots (Fig. 2b-d) generated using the statistical software. These plots show the effects of independent variables as well their combined effect on the response, i.e., protease activity. They also show the predicted value of the protease activity at the optimized concentrations of the selected variables. The model was validated by performing the experiment under the predicted set of conditions indicated by the perturbation plot (Fig. 2e). The response obtained (17.5 U/mg protein) was very close to the predicted response (17.6 U/mg protein), thus the validity of the model was proved. Factorial design caused a 1.75 fold $(75 \%)$ increase in the production of protease by $S$. marcescens PPB-26.

\section{Optimization of reaction conditions}

\section{Buffer system and $\mathrm{pH}$}

1.5 $\mathrm{M}$ tris- $\mathrm{HCl}$ buffer at $\mathrm{pH} 7.5$ was found to be the most appropriate buffer $(17.7 \mathrm{U} / \mathrm{mg}$ protein) for protease activity of $S$. marcescens PPB-26 protease.

\section{Reaction temperature}

Maximum enzyme activity (17.8 U/mg protein) was recorded at $30{ }^{\circ} \mathrm{C}$. The proteolytic activity stayed stable till $40{ }^{\circ} \mathrm{C}$, but beyond it there was a steady decline in activity.

\section{Substrate concentration}

The effect of substrate (casein) concentration (0.1-1.0\%) on protease activity of $S$. marcescens PPB-26 was studied and maximum activity ( $20 \mathrm{U} / \mathrm{mg}$ protein) was observed at
$0.8 \%$ casein. At higher concentrations decline in activity was recorded.

\section{Determination of $K_{m}$ and $V_{\max }$}

The protease of $S$. marcescens PPB-26 followed normal Lineweaver-Burk plot up to $0.3 \%$ casein. The analysis of Lineweaver-Burk plot showed that the protease had $K_{\mathrm{m}}=0.3 \%$ and $V_{\max }=34.5 \mu \mathrm{mol} \mathrm{min} \mathrm{mg}^{-1} \mathrm{mg}^{-1}$ protein (Fig. 3).

\section{Reaction time}

For optimizing reaction time, protease assay was carried out for $60 \mathrm{~min}$ and tyrosine produced in the reaction mixture was recorded at regular interval. Ten minutes was found to be the shortest duration during in which highest tyrosine concentration $(35 \mu \mathrm{g} / \mathrm{ml})$ is produced. Beyond this the rate of increase in tyrosine concentration remained same.

\section{Effect of metal ions}

$\mathrm{Co}^{2+}$ (16.6 U/mg protein) and $\mathrm{Mn}^{2+}(18 \mathrm{U} / \mathrm{mg}$ protein) inhibited the protease activity, whereas $\mathrm{Fe}^{2+}(22.5 \mathrm{U} / \mathrm{mg}$ protein) and $\mathrm{Cu}^{2+}(21.8 \mathrm{U} / \mathrm{mg}$ protein) had an incremental effect. Other metal ions $\left(\mathrm{Ca}^{2+}, \mathrm{Cu}^{2+}, \mathrm{Zn}^{2+}\right.$ and $\left.\mathrm{Mg}^{2+}\right)$ had no major effect on the protease activity.

\section{Effect of $\mathrm{NaCl}$}

The protease activity of $S$. marcescens PPB-26 stayed stable (17 U/mg protein) with up to $0.9 \mathrm{M}$ concentration of $\mathrm{NaCl}$. 
Fig. 2 a Pareto chart showing positive and negative factors for protease production by $S$. marcescens PPB-26. b Three dimensional response surface plot for the effect of $(A) \mathrm{CaCl}_{2}$ and $(B)$ Yeast extract on protease production by $S$. marcescens PPB-26. c Three dimensional graph showing effect of two variable interaction $(A) \mathrm{KH}_{2} \mathrm{PO}_{4}$ and

(C) $\mathrm{CaCl}_{2}$ on protease production. d Three dimensional (3D) graph showing effect of two variable interaction effect $(B) \mathrm{KH}_{2} \mathrm{PO}_{4}$ and $(C)$ Yeast extract on protease production. e Perturbation plot showing the optimum value for optimized variables a

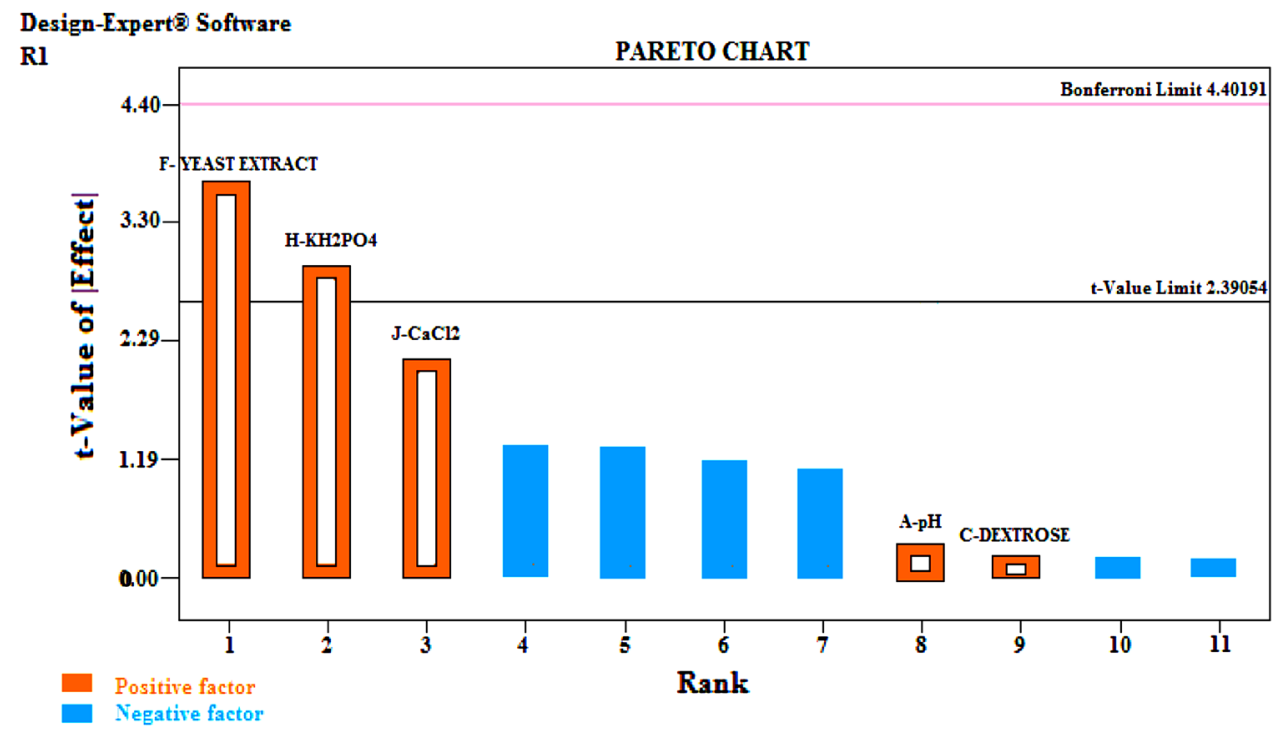

b

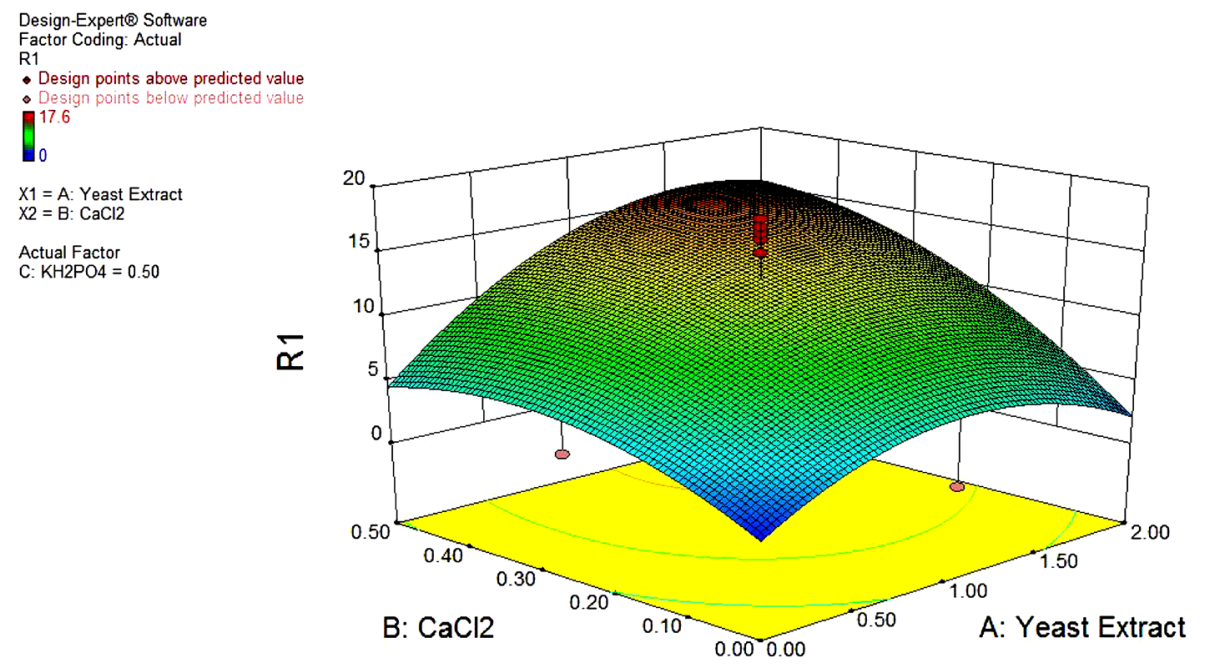

Stability in organic solvents

The protease enzyme was found to be stable in most organic solvents (Fig. 4) except in isopropanol in which the activity was severely reduced. Maximum stability in the protease activity was recorded with methanol $(99 \%)$ and ethanol $(96 \%)$.

\section{Discussion}

Application of enzymes instead of chemicals in the industry is preferred as it provides for a cheaper and more environment friendly alternative. This study was focused on isolation and screening of bacteria from soils of Himachal Pradesh for high protease activity. Soil has served as source of numerous protease producing bacteria such as B. megaterium (Asker et al. 2013). After exhaustive screening a hyper producer of protease was selected which phenotypically resembled the earlier reported S. marcescens strain SA1 (HM136580.1). The isolate $S$. marcescens PPB-26 showed highest protease activity in GYC medium while lowest in M4 medium (soybean meal medium). Soybean has anti-trypsin inhibitors which reduce the protein digesting capability (Haard et al. 1996). Among different carbon sources, glucose was the most preferred while sucrose, fructose and galactose were least preferred for protease production by $S$. marcescens PPB-26. Glucose has previously been reported as a suitable carbon source for protease production in S. marcescens (Mohankumar 2011). Joshi et al. (2007) reported fructose as preferred carbon source for 
Fig. 2 continued

C

Design-Expert@ Software

Factor Coding: Actua

R1

- Design points above predicted value

- Design points below predicted value

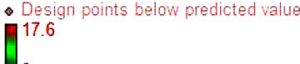

$\mathrm{X} 1=\mathrm{B}: \mathrm{CaCl} 2$

$\mathrm{X} 2=\mathrm{C}: \mathrm{KH} 2 \mathrm{PO} 4$

Actual Factor

A: Yeast Extract $=1.00$

$\bar{x}$

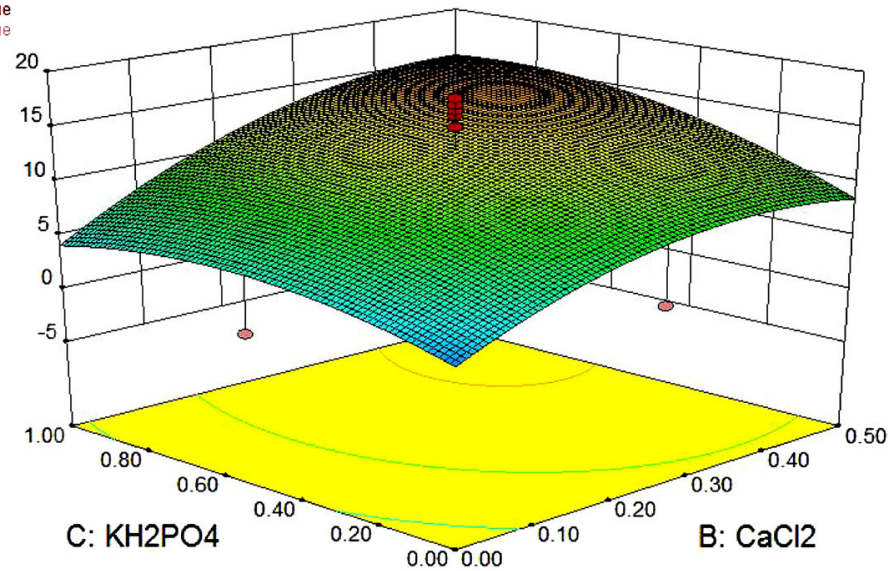

d

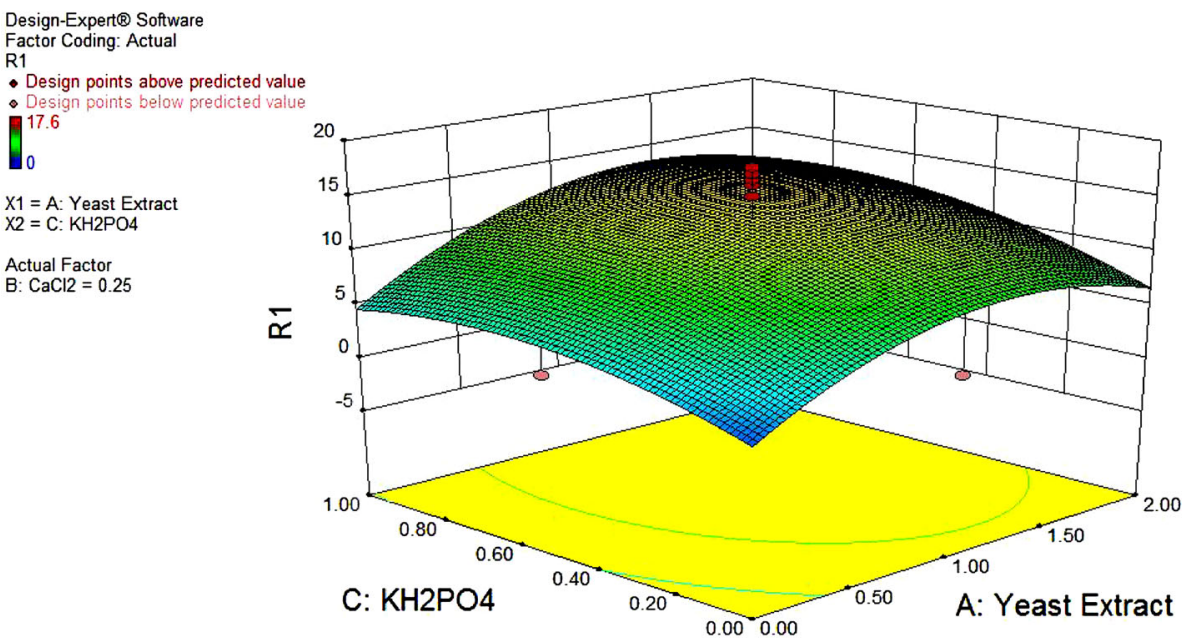

e Design-Expert@ Software Factor Coding: Actual R1

Actual Factors A: Yeast Extract $=1.00$ B: $\mathrm{CaCl} 2=0.25$ C: $\mathrm{KH} 2 \mathrm{PO} 4=0.50$

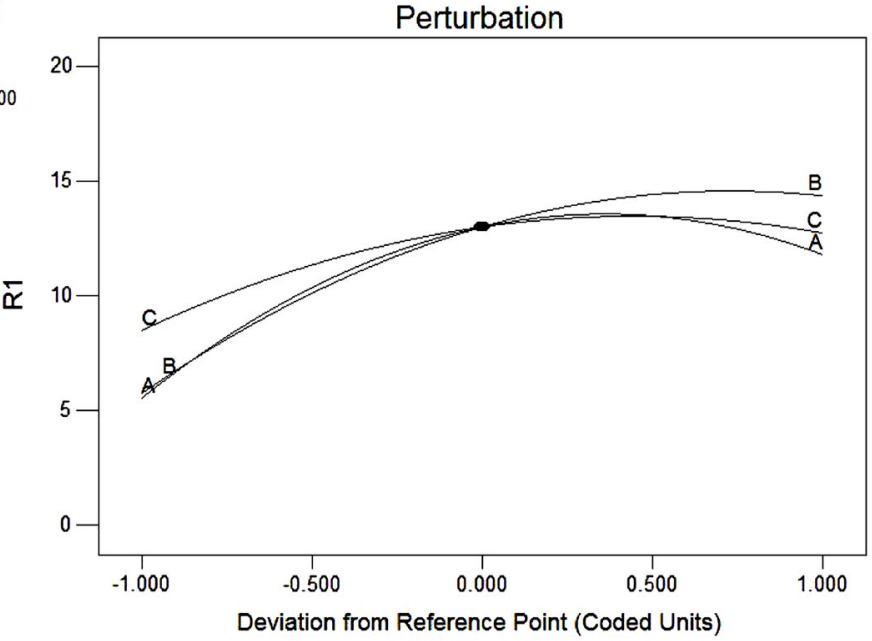

protease production by B. cereus MTCC 6840. Among nitrogen sources, organic sources were better for protease production than inorganic sources which resulted in decreased protease activity. A similar trend has been reported in serration peptidase enzyme of $S$. marcescens (Mohankumar 2011). Of different metal ions studied most 
Table 3 Central composite experimental design

\begin{tabular}{lllll}
\hline Run & Yeast Extract $(\%)$ & $\mathrm{CaCl}_{2}(\%)$ & $\mathrm{KH}_{2} \mathrm{PO}_{4}(\%)$ & Response (U/mg protein) \\
\hline 1 & 1.0 & 0.25 & 0.5 & 4.9 \\
2 & 0 & 0.25 & 0.5 & 3.0 \\
3 & 0.02 & 0 & 0.5 & 0 \\
4 & 2.67 & 0.25 & 1.0 & 5.3 \\
5 & 1.0 & 0.25 & 0.5 & 16 \\
6 & 1.0 & 0.25 & 0.5 & 15 \\
7 & 0.02 & 0.5 & 1.0 & 4.0 \\
8 & 2.0 & 0.5 & 1.0 & 17 \\
9 & 1.0 & 0.25 & 0 & 3.0 \\
10 & 1.0 & 0.25 & 1.34 & 10 \\
11 & 1.0 & 0 & 0.5 & 0.5 \\
12 & 1.0 & 0.25 & 0.5 & 16.5 \\
13 & 0.2 & 0 & 0 & 0 \\
14 & 1.0 & 0.25 & 0.5 & 17 \\
15 & 1.0 & 0.67 & 0.5 & 12 \\
16 & 2.0 & 0 & 1.0 & 1.0 \\
17 & 2.0 & 0 & 0 & 0.8 \\
18 & 0.02 & 0.5 & 0 & 1 \\
19 & 1.0 & 0.25 & 0.5 & 17.6 \\
20 & 2.0 & 0.5 & 0 & 9 \\
\hline
\end{tabular}

showed no effect on enzyme activity except manganese chloride which had an inhibitory effect and calcium chloride which increased protease activity. Metal ions stabilize and enhance the production and activity of protease enzyme (Janssen et al. 1994). Calcium has been reported to enhance protease production in Pseudomonas aeruginosa (Marquart et al. 2005). Not many reports of statistical optimization of protease production have been reported. In this study $S$. marcescens PPB-26 protease production was optimized using the Response Surface Methodology. Factorial designing increased the production by 1.75 fold (75 \%). In P. aeruginosa MCM B3271.3 fold increase was reported (Zambare et al. 2013).

Serratia marcescens PPB-26 protease showed activity in $\mathrm{pH}$ range of 6-9 with maximum activity at $\mathrm{pH} 7.5$ in $1.5 \mathrm{M}$ Tris-HCl buffer. Ionic strength of buffer did not have much effect on the enzyme activity. Optimum temperature for enzyme activity was found to be $30{ }^{\circ} \mathrm{C}$, at higher temperatures beyond $40{ }^{\circ} \mathrm{C}$ the activity decreased. The enzyme faced product inhibition at concentrations above $0.8 \%$ casein due to product accumulation in the reaction mixture. Among metal ions $\mathrm{Co}^{2+}, \mathrm{Zn}^{2+}$ and $\mathrm{Mn}^{2+}$ had negative effect on the protease activity, whereas $\mathrm{Fe}^{2+}$ had a positive effect on it. Similar results with metal ions have been reported previously also (Yang et al. 2000). The protease of S. marcescens PPB-26 showed tolerance to high $(0.9 \mathrm{M})$ $\mathrm{NaCl}$ concentrations. Decrease in activity at higher $\mathrm{NaCl}$ concentrations might be due to the precipitation of substrate at high salinities. The protease of Bacillus sp. NG-27

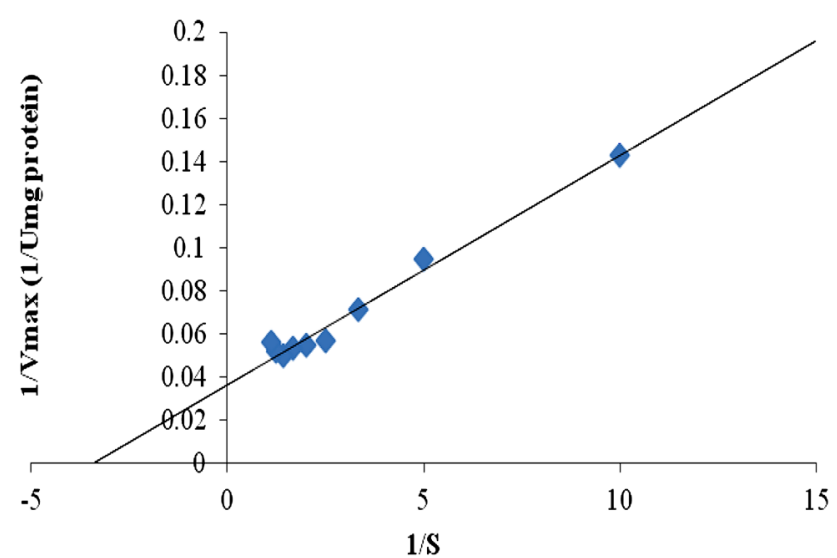

Fig. 3 Lineweaver-Burk plot for the protease of $S$. marcescens PPB-26

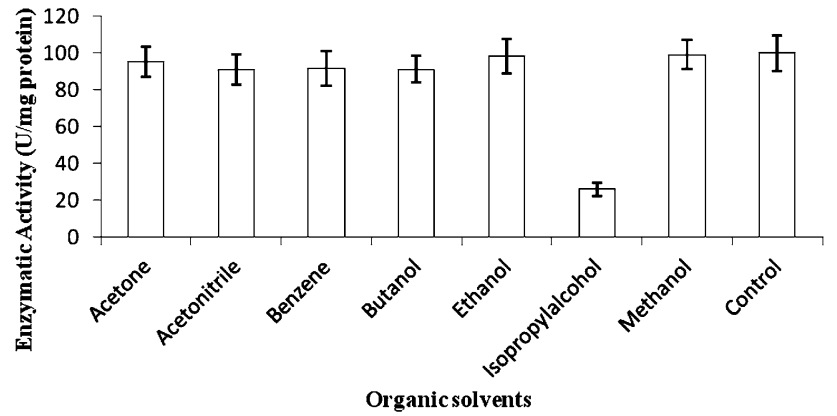

Fig. 4 Effect of organic solvents on protease activity of S. marcescens PPB-26 
has also been reported to exhibit high salt tolerance ( $\mathrm{Su}-$ mandeep et al. 1999).

Organic solvents are used as reaction media for enzymes in various industrial processes due to advantages like high regio- and stereo-selectivity and minimal side-chain protection requirements (Kumar and Bhalla 2005). However, most enzymes show low activity in organic solvents due to limited diffusion, partial denaturation and reduced flexibility (Kwon et al. 1999). The protease of S. marcescens PPB-26 showed stability in all organic solvents (50\% v/v) over $24 \mathrm{~h}$, except in isopropanol. This property makes it useful for industrially important applications like peptide synthesis. The enzyme showed maximum stability (95-100\%) with toxic organic solvents like methanol and ethanol, unlike the previously reported proteases of $B$. tequilensis P15 Bose et al. 2014) and Virgibacillus sp. EMB13 (Sinha and Khare 2012) in which the relative activity was $2 \%$ (in methanol) and $45 \%$ (in ethanol), respectively.

\section{Conclusion}

This study reports an organic solvent tolerant protease from S. marcescens PPB-26 which shows activity in a broad range of temperature and $\mathrm{pH}$. Stimulation of proteolytic activity in presence of $\mathrm{CaCl}_{2}$ is an interesting characteristic as very few reports of such effects exist in literature. The enzyme's stability in the presence of a wide range of organic solvents, metal ions as well as salinity indicates its huge potential in various industrial applications such as peptide synthesis and as a detergent additive.

Acknowledgments The authors acknowledge the Council of Scientific and Industrial Research (CSIR), India for financial support in the form of Senior Research Fellowship to Ms. Shikha Thakur and the University Grants Commission, India for fellowships to Ms. Savitri, Mr. Nirmal Kant Sharma and Ms. Neerja Thakur. The computational facility availed at Bioinformatics Centre, Himachal Pradesh University is also duly acknowledged.

Open Access This article is distributed under the terms of the Creative Commons Attribution 4.0 International License (http:// creativecommons.org/licenses/by/4.0/), which permits unrestricted use, distribution, and reproduction in any medium, provided you give appropriate credit to the original author(s) and the source, provide a link to the Creative Commons license, and indicate if changes were made.

\section{References}

Ajithkumar B, Ajithkumar VP, Iriye R, Doi Y, Sakai T (2003) Spore forming Serratia marcescens subsp. sakuensis subsp. nov., isolated from a domestic wastewater treatment tank. Int J Syst Evol Microbiol 53:253-258
Annapurna SA, Singh A, Garg S, Kumar A, Kumar H (2012) Production and characterization of thermo tolerant alkaline protease from Serratia marcescens. Asian J Microbiol Biotechnol Environ Sci 14:591-596

Asker MS, Mahmoud MG, Shebwy KE, Abdel Aziz MS (2013) Purification and characterization of two thermostable protease fractions from Bacillus megaterium. J Gen Eng Biotechnol 1:103-109

Barrett AJ, Rawlings ND (1995) Proteolytic enzymes: aspartic and metallo peptidases. Methods Enzymol 248:146-155

Barrett AJ, Rawlings ND, Brien EA (2001) The MEROPS database as protease information system. J Strut Biol 14:95-102

Bhalla TC, Kumar D, Gajju H, Agrawal HO (1999) Thermophilic bacterial proteases. J Punj Aaca Sci 1:77-91

Bhaskar N, Sudeepa ES, Rashmi HN, Tamil Selvi A (2007) Partial purification and characterization of protease of Bacillus proteolyticus CFR3001 isolated from fish processing waste and its antibacterial activities. Bioresour Technol 98:2758-2764

Bose A, Chawdhary V, Keharia H, Subramanian RB (2014) Production and characterization of a solvent-tolerant protease from a novel marine isolate Bacillus tequilensis P15. Ann Microbiol 64:343-354

Chu IM, Lee C, Li TS (1992) Production and degradation of alkaline protease in batch cultures of Bacillus subtilis ATCC 14416. Enzyme Microb Technol 14:755-761

Davis BG (2003) Chemical modification of biocatalysts. Curr Opin Biotechnol 14:379-386

Gupta R, Beg QK, Lorenz P (2002) Bacterial alkaline proteases: molecular approaches and industrial applications. Appl Microbiol Biotechnol 59:15-32

Haard NF, Dimes LE, Arndt RE, Dong FM (1996) Estimation of protein digestibility: IV. Digestive proteinases from the pyloric caeca of coho salmon Z Oncorhynchus kisutch fed diets containing soybean meal. Comp Biochem Physiol 115:533-540

Janssen PH, Peek K, Morgan HW (1994) Effect of culture conditions on the production of an extracellular protienase by Thermus sp. Rt41A. Appl Microbiol Biotechnol 41:400-406

Jellouli K, Bougatef A, Manni L, Agrebi R, Siala R et al (2009) Molecular and biochemical characterization of an extracellular serine protease from Vibrio etschnikovii. J Ind Microbiol Biotechnol 36:939-948

Joshi GK, Kumar S, Sharma V (2007) Production of moderately halotolerant, SDS stable alkaline protease from Bacillus cereus MTCC 6840 isolated from lake Nainital, Uttaranchal state, India. Braz J Microbiol 38:773-779

Kim HS, Golyshin PN, Timmis KN, Kim HS, Golyshin PN et al (2007) Characterization and role of a metalloprotease induced by chitin in Serratiasp. KCK. J Ind Microbiol Biotechnol 34:715-721

Kobayashi T, Hakamada Y, Adachi S, Hitomi J, Yoshimatsu T et al (1995) Purification and properties of an alkaline protease from alkalophilic Bacillus sp. KSM-K16. Appl Microbiol Biotechnol 43:473-481

Kocher GS, Mishra S (2009) Immobilization of Bacillus circulans MTCC 7906 for enhanced production of alkaline protease under batch and packed bed fermentation conditions. Int J Microbiol 7:359-378

Kumar D, Bhalla TC (2005) Microbial proteases in peptide synthesis: approaches and applications. Appl Microbiol Biotechnol 68:726-736

Kwon OH, Imanishi Y, Ito Y (1999) Catalytic activity and conformation of chemically modified subtilisin Carlsberg in organic media. Biotechnol Bioeng 66:265-270

Manachini PL, Fortina MG, Parini C (1988) Alkaline protease produced by Bacillus thermoruber-a new species of Bacillus. Appl Microbiol Biotechnol 28:409-413 
Marquart ME, Dajcs JJ, Caballero AR, Thibodeaux BA, O'Callaghan RJ (2005) Calcium and magnesium enhance the production of Pseudomonas aeruginosa protease IV, a corneal virulence factor. Med Microbiol Immunol 194:39-45

Matta H, Punj V, Kanwar SS (1997) An immuno-dot blot assay for detection of thermostable protease form Psudomonassp. AFT-36 of dairy origin. Appl Microbiol 25:300-302

Miyoshi S, Shinoda S (2000) Microbial metalloproteases and pathogenesis. Microb Infect 2:91-98

Mohankumar A (2011) Production and characterization of serratiopeptidase enzyme from Serratia marcescens. Int J Biol 3:3

Morihara K (1987) Using proteases in peptide synthesis. Trend Biotechnol 5:164-170

Morita Y, Kondoh K, Hasan Q, Sakaguchi T, Murakami Y et al (1997) Purification and characterization of a cold-active protease from psychrotrophic Serratiamarcescens AP3801. J Am Oil ChemSoc 74:1377-1383

Noritomi H, Suzuki K, Kikuta M, Kato S (2009) Catalytic activity of $\alpha$-chymotrypsin in enzymatic peptide synthesis in ionic liquids. Biochem Eng J 47:27-30

Purva Soni SK, Gupta LK, Gupta JK (1998) Thermostable alkaline protease from alkalophilic Bacillus sp. IS-3. Indian J Microbiol 38:149-152

Rao MB, Tanksale AM, Ghatge MS, Deshpande VV (1998) Molecular and biotechnological aspects of microbial proteases. Microbiol Mol Biol Rev 62:597-635

Ru MT, Hirokane SY, Lo AS, Dordick JS, Reimer JA et al (2000) On the salt-induced activation of lyophilized enzymes in organic solvents: effect of salt kosmotropicity on enzyme activity. J Am Chem Soc 122:1565-1571

Sinha R, Khare SK (2012) Isolation of a halophilic Virgibacillus sp. EMB13: characterization of its protease for detergent applications. Indian J Biotechnol 11:416-426
Sinha N, Satyanarayana T (1991) Alkaline protease by thermophilic Bacillus licheniformis. Indian J Microbiol 31:425-430

Sumandeep Bhushan B, Beg QK, Hoondal GS (1999) Partial purification and characterization of a thermostable alkaline protease of an alkalophilic Bacillus sp. NG 27. Indian J Microbiol 39:185-187

Tsuchida O, Yamagota Y, Ishizuka J, Arai J, Yamada J et al (1986) An alkaline protease of an alkalophilic Bacillus sp. Curr Microbiol 14:7-12

Tsuchiya H, Sakashita Y, Nakamura T, Kimura T (1991) Production of thermostable alkaline protease by alkalophilic Thermoactinomyces sp. HS682. Agric Biol Chem 55:3125-3127

Tsujibo H, Miyamoto K, Hasegawa T, Inamori Y (1990) Purification and characterization of two types of alkaline serine proteases produced by an alkalophilic actinomycetes. J Appl Bacteriol 69:520-529

Upadhyay MK, Kumar R, Kumar A, Gupta S, Kumari M et al (2010) Optimization and characterization of an extracellular protease from Aspergillusflavus MTCC 27. Af J Agri Res 5:1845-1850

Vulfson EN, Halling PJ, Holland HL (2001) Enzymes in non aqueous solvents: methods and protocols. Humana Press Inc., New York

Wolff AM, Showell MS, Venegas MG, Barnett BL, Wertz WC (1996) Laundry performance of subtilisin proteases. Adv Exp Med Biol 379:113-120

Yang JK, Shih IL, Tzeng YM, Wang SL (2000) Production and purification of protease from Bacillus subtilis that can deproteinize crustacean wastes. Enzyme MicrobTechnol 26:406-413

Zambare VP, Nilegaonkar SS, Kanekar PP (2013) Protease production and enzymatic soaking of salt-preserved buffalo hides for leather processing. IIOAB Letters 3:1-7 